UDC 37.014.2(477.83/.86)"18"

DOI: 10.24919/2519-058x.16.211182

\title{
Andrii SLUSARENKO
}

PhD hab. (History), Associate Professor, Deputy Commander of the Academy for scientific work, Hetman Petro Sahaidachnyi National Army Academy, 32 Heroiv Maidanu Street, Lviv, Ukraine, postal code 79026 (savnvp@gmail.com)

ORCID: https://orcid.org/0000-0001-7812-6277

\section{Tetiana KOLOMOETS}

PhD hab. (Law), Professor, Honoured Lawyer of Ukraine, Corresponding Member of the National Academy of Legal Sciences of Ukraine, Dean of Law Faculty of Zaporizhzhya National University, 66 Zhukovskyi Street, Zaporizhzhia, Ukraine, postal code 69002 (t_deputy@ukr.net)

ORCID: https://orcid.org/ 0000-0003-1101-8073

ResearcherID: M-9082-2019 (http://www.researcherid.com/rid/ M-9082-2019)

\section{Андрій СЛЮСАРЕНКО}

доктор історичних наук, доцент, заступник начальника академії з наукової роботи, Національна академія Сухопутних військ імені гетьмана Петра Сагайдачного, вул. Героїв Майдану, 32, Львів, індекс 79026 (savnvр@gmail.com)

\section{Тетяна КОЛОМОЕЦь}

докторка юридичних наук, професорка, член-кореспондентка Національної академії правових наук України, заслужений юрист України, декан юридичного факультету Запорізького національного університету, вул. Жуковського, 66, м. Запоріжжя, Україна, індекс 69002 (t_deputy@ukr.net)

Бібліографічний опис статті: Slusarenko, A. \& Kolomoets, Т. (2020). “The Memorial” of public school teachers of Bibrka county of the Kingdom of Galicia and Lodomeria (1891) as a historical and legal source. Skhidnoievropeiskyi Istorychnyi Visnyk [East European Historical Bulletin], 16, 112-126. doi: 10.24919/2519-058x.16.211182

\section{"THE MEMORIAL" OF PUBLIC SCHOOL TEACHERS OF BIBRKA COUNTY OF THE KINGDOM OF GALICIA AND LODOMERIA (1891) AS A HISTORICAL AND LEGAL SOURCE}

\begin{abstract}
The purpose of the article is to publish and analyze "The Memorial" of public schools teachers of Bibrka school district (1891) as the source for the history of schooling in Galicia and the socio-legal culture of teachers at the end of the XIXth century. The research methodology principles of scientific, objectivity, historicism, methods of external and internal critique of sources. The research novelty is that "The Memorial" of public schools teachers of Bibrka school district (1891) was first published and analyzed as a historical and legal source. The Conclusions. Thus, the analyzed "The Memorial" is an extremely interesting historical source, which reveals the level of a social, professional and group activity and solidarity of teachers in the small county of Galicia at the end of the XIXth century. The project elaborated by them, despite the completely uncalculated costs
\end{abstract}


for its implementation, deserves attention, primarily, to the principles that teachers proposed to base the system of "advance": linking the amount of salary (the transition from a lower to higher salary) to the personal success of a teacher, his qualification, experience. At the same time, "The Memorial" testified to the existence of a certain civil position of teachers, who, although timidly, protested against the unsatisfactory social situation, injustices in the provision of a post (the right to "presents", the arbitrariness of officials), holding posts by unskilled and casual people in a pedagogical profession; the authors of 1The Memorial" emphasized the negative effects of the protection mechanism (indirectly pointing at corruption in this regard) on the morality of teachers and the quality of education, and etc. It should be noted that the document was signed by both Polish and Ukrainian teachers, who pushed aside their interethnic contradictions in the field of defending the interests of their own professional group. The document is a clear proof of the growth of a legal and social culture of "folk teachers", who gradually became aware of their social importance and dared to take on the role of an active subject in solving the most painful problems of an educational life. The document is published in the original language (Polish) in compliance with the necessary archaeographic requirements.

Key words: "The Memorial" of public schools teachers of Bibrka school district, Kingdom of Galicia and Lodomeria, State School Council, financial situation of teachers.

\title{
“МЕМОРІАЛ" УЧИТЕЛІВ НАРОДНИХ ШКІЛ БІБРСЬКОГО ПОВІТУ КОРОЛІВСТВА ГАЛИЧИНИ І ЛОДОМЕРІЇ (1891) ЯК ІСТОРИКО-ПРАВОВЕ ДЖЕРЕЛО
}

\begin{abstract}
Анотація. Мета статті - опублікувати й проаналізувати "меморіал” вчителів народних шкіл Бібрського шкільного округу (1891) як джерело до історії шкільнищтва Галичини та соиіально-правової культури вчительства кіния ХIX ст. Методологія дослідження - принципи науковості, об'єктивності, історизму, методи зовнішньої та внутрішньої критики джерел. Наукова новизна полягає у тому, що уперше публікується "меморіал" вчителів народних шкіл Бібрського шкільного округу (1891) та здійснюється його аналіз як історико-правового джерела. Висновки. Отже, аналізований “меморіал" є надзвичайно иікавим історичним джерелом, який виявляє рівень сочіальної, професійно-групової активності і солідарності вчителів маленького повіту Галичини наприкіниі XIX cm. Розроблений ними проєкт, незважсаючи на зовсім непрораховані видатки для його реалізаиії, заслуговує на увагу передовсім принципами, які педагоги пропонували покласти в основу системи “авансу": прив'язання розміру платні (перехід від нижчого до вищого класу оплати) до особистих успіхів вчителя, його кваліфікованості, досвідченості. Водночас “меморіал” засвідчив наявність певної громадянської позичії вчителів, які, хоч і несміливо, протестували проти незадовільного сочіального становища, несправедливостей щцодо надання посади (право “презенти”, свавілля чиновників), займання посад некваліфікованими й випадковими у педагогічній професії людьми, підкреслили негативні впливи механізму протекції (непрямо вказавши на корупиію у цьому плані) на моральність вчителя $і$ якість освіти тощо. Зауважимо, що документ підписали як вчителі-поляки, так і вчителі-українці, які на полі відстоювання інтересів власної професійної групи відсунули у бік свої міжнаціональні суперечності. Документ є яскравим доказом зростання правової і соиіально-станової культури “народних учителів", які поступово усвідомлювали свою суспільну вагу й наважувалися брати на себе роль активного суб' 'кта у розв 'язанні найбільш болючих проблем організації освітнього життя. Документ публікується мовою оригіналу (польською) з дотриманням необхідних археографічних вимог.
\end{abstract}

Ключові слова: “Меморіал” вчителів народних шкіл Бібрського шкільного округу, Королівсто Галичини і Лодомерії, Краєва шкільна рада, матеріальне становище вчителів.

The Problem Statement. The study of the history of social groups and the population strata, including teachers, is based on a wide range of different historical sources, among which an important place occupy the documents of a collective authorship (the statutes, memorials, projects, meetings and conferences decisions, etc.). They reflect the representatives' views of certain groups on themselves and give the opportunity to form a clear idea of their 
understanding of their own problems, objectives, rights and needs. Among the sources on the history of teaching in the Kingdom of Galicia and Lodomeria in the second half of the XIXth century, of great interest were the appeals initiated by the teachers themselves to the authorities, first of all the State School Council (hereinafter - the SSC), on various issues that concerned teachers at a certain historical stage. One of such appeals is "The Memorial" of teachers of Bibrka County to the SSC (1891) concerning the material and legal situation of primary school teachers. "The Memorial" needs a special attention of researchers.

The Analysis of Recent Researches. The situation of primary (folk) school teachers in Galicia during the XIXth - the beginning of the XXth centuries was described by the contemporary scientists: I. Fylypchak (Fylypchak, 2009), I. Franko (Franko, 1986a, 1986b), the educators M. Lozynskyi (Lozynskyi, 1906), H. Schmitt (Schmitt, 1874), a writer Yu. Shnaider (Uliana Kravchenko) (Kravchenko, 1975) and the others. They usually elucidated the poor material situation of public school teachers, often criticizing the government's primary education policy and demanding to increase the budget expenditures for teachers. "Last year, - I. Franko wrote in 1892, - to the scoff of the whole world, there were two such cases in Galicia when teachers at work died of starvation. Our teacher earns less than the first-best coachman in court or a guard in crime cases" (Franko, 1986a, pp. 113-114). The Polish educators and researchers B. Baranowski (Baranowski, 1910), M. Baranowski (Baranowski, 1896), T. Fiutowski (Fiutowski, 1913) also outlined the issue of unsatisfactory wages of teachers, often emphasizing the authorities' efforts to improve the financial situation of teachers. The miserable situation of Galician teachers was vividly described by Z. Mayer (Mayer, 1899), who provided many examples of being deprived of rights and poverty of teachers. The Soviet researchers L. Baik and B. Mitiurov (Baik \& Mitiurov, 1965) from the class point of view, characterizing the situation of teacher, emphasized the poor material security of teachers, which was explained by bourgeois-capitalist oppression. Modern Ukrainian and Polish researchers (F. Rzemieniuk (Rzemieniuk, 1991), B. Stuparyk (Stuparyk, 1994), V. Blahyi (Blahyi, 1999), R. Petriv (Petriv, 2002), V. Stynska (Stynska, 2004), L. Sholohon (Sholohon, 2004), T. Vorobkevych and A. Vorobkevych (Vorobkevych \& Vorobkevych, 2007), M. Haliv (Haliv, 2011), A. Varianytsa (Varianytsa, 2018) and the others) study the quantitative and qualitative indicators of Galician teaching, analyze the government's policy on the material support, characterize the everyday life of teachers.

It should be noted that none of the above-mentioned researchers cited in their works "The Memorial" of public schools teachers of Bibrka school district (hereinafter -"The Memorial") as a separate historical source. This document was briefly mentioned only in A. Varanytsia's dissertation (Varianytsa, 2018). At present, "The Memorial” has not been published and analyzed from the point of a historical archeography.

The purpose of the article is to publish and analyze "The Memorial" of public schools teachers of Bibrka school district (1891) as the source for the history of schooling in Galicia and the socio-legal culture of teachers at the end of the XIXth century.

The Statement of the Basic Material. After the adoption of the Constitution and the acquisition of a limited autonomy by the Kingdom of Galicia and Lodomeria in the Habsburg Empire (1867), the reform period began in the field of education: nationalization of parish and public schools, unification of school structure, modernization of curricula and programmes, teachers training in the state teacher's seminaries, etc. Under these conditions, the number of Galician teachers gradually increased, which, on the one hand, was the result of a purposeful policy of the authorities to expand the network of elementary and other schools, on the 
other hand - a certain, although quite insignificant, improvement in the financial situation of teachers.

The founders of the school were responsible for the salary of a village teacher: the community of the city or village, the private tabular estate, the state. During the second half of the XIXth - the beginning of the XXth century there were some changes in the amount of salary of primary school teachers. According to the law of May 14, 1869, teachers had to be set a salary that would allow them to devote themselves entirely to their work, free from extracurricular activities. The regional school law of 1873 completely forbade teachers to perform other functions for part-time work. In general, public school teachers were divided into five job classes, according to which the salaries were calculated. Teachers of Class I (teachers of Lviv and Krakow) received 700 zl., teachers of Class II (teachers in towns with more than 10000 of inhabitants) - $600 \mathrm{zl}$., and teachers of Class III (in communities with a population of $6000-10000$ of inhabitants) - $500 \mathrm{zl}$., teachers of Class IV (in urban communities with $2000-6000$ of inhabitants) $-450 \mathrm{zl}$., teachers of Class V (in rural communities with a population of $2000-6000)-400 \mathrm{zl}$. If the commune (gmina) had less than 2000 inhabitants, the teacher could receive about $300 \mathrm{zl}$. The work of a junior or temporary teacher was to be $60 \%$ of the salary of a full-time teacher. However, in no case could it be lower than $200 \mathrm{zl}$. per year (Haliv, 2011, p. 51). In fact, this was the lowest salary $(200-300 \mathrm{zl}$.) received by most teachers of public schools in Bibrka County (as well as other counties in Galicia) during the 1870-ies and 1890-ies.

"The Memorial" of public schools teachers of Bibrka school district is in the Central State Historical Archive of Ukraine in Lviv (Fonds 178: State School Council, description 1, case 1136,8 p.). This is a manuscript document written in Polish in the county town of Bibrka in Galicia and dated on October 10, 1891. It was signed by 76 primary (folk) teachers of Bibrka school district (CSHAUL, f. 178, d. 1, c. 1136, pp. 6a-7), whose boundaries coincided with the administrative boundaries of Bibrka County.

At that time, there were 73 primary schools in Bibrka County, in which there were employed 102 public teachers (Szematyzm, 1891, pp. 416-417). Therefore, this document was signed by the vast majority of county teachers (74,5\%). Most likely, the "The Memorial" was made during the general conference of school district teachers, which a school inspector had to summon annually.

It should be noted that this document was called "The Memorial" by the teachers themselves, but in its content it corresponds to the concept of "petition", which means an individual or collective request, appeal, proposal, complaint, request, petition submitted to the public authorities in a written form. However, we assume that teachers did not dare to call their appeal a "petition" to the SSC as the highest governmental institution in Galicia in the field of education. The latter (a "petition") could be interpreted as a manifestation of an open dissatisfaction on the part of teachers with the school authorities policy. And this would certainly incur teachers (especially the initiators of writing such a "petition") to a disciplinary action. Under such circumstances, in our opinion, teachers used a less irritating name for their address to the SSC - "The Memorial".

In general, the document is in the form of a request to improve the material support of primary school teachers in Austrian Galicia. Its content can be divided into four parts: 1) an introductory address to the SSC, which contains emphasis on the social importance of teaching, its importance for the progress and development of the nation; 2) the description of the unsatisfactory material and social situation of teachers in Galicia; 3 ) the proposals for 
improving the system of remuneration of teachers, their material incentives; 4) the final part, full of compliments for the SSC and assurances of teachers' loyalty.

In the first, rather short, part, the authors of "The Memorial" emphasized the role of teachers in spreading education and upbringing of the nation (CSHAUL, f. 178, d. 1, c. 1136, p. 1). It should be noted that the appeal to the nation-building role of teachers at the end of the XIXth century was extremely common in a social and political journalism. At the same time, the words of the German "Iron Chancellor" Otto von Bismarck about teachers as builders of the state were repeatedly mentioned in the press. From the document analyzed by us, we see that teachers had an awareness of the paramount importance of pedagogical work, its special role in the society, the formation of national, political and social visions of the people.

The second part of the document is the largest and quite eclectic in content. On the one hand, the authors of "The Memorial" emphasize the needy miserable financial situation of primary school teachers. They complain about: a) the existence of the "economy system" in the school budget of the region - the Kingdom of Galicia and Lodomeria, which negatively affects the development of schooling; b) a low level of teachers' salary, which is absolutely not enough "for the needs faced by the teacher in view of his position in the society, but even for the most modest maintenance of one person the salary is low, not to mention those, who have a family" (CSHAUL, f. 178, d. 1, c. 1136, pp. 1v-2); c) because of a miserable situation, there was a widespread distrust among teachers concerning the improvement of their situation, which made them quit their jobs and search for the positions in various governments; d) while qualified teachers quit their jobs, teachers' vacancies are increasingly occupied by unskilled persons; e) young graduates of teachers' seminaries do not want to go to work at school either, looking for positions in the railway, post office, tax governments, etc. (CSHAUL, f. 178, d. 1, c. 1136, p. 2). There was the accusation of the prosperity of the "protection system / favourism system", under the conditions of which a recent graduate of a teacher's seminary, having protection, gets a better position than a teacher, who works for a long time (CSHAUL, f. 178, d. 1, c. 1136, p. 4).

On the other hand, the teachers of the schools of Bibrka County in "The Memorial" strongly emphasized the desire of the SSC to improve the funding conditions for primary school teachers. Reproaching the authorities, they use the abstract, in this case, the concept of "land": "our land treats teaching and schooling, in general, as a stepmother" (CSHAUL, f. 178 , d. 1, c. 1136 , p. 1 v). Nevertheless, the authors of the "The Memorial" wrote about the good regional school law of 1873, which "put teachers in an important position in the society, thus recognizing their all rights and privileges". They did not forget to note that the SSC understood the problem of an unsatisfactory funding of teachers. They were grateful to the SSC for the order, according to which unqualified teachers were forbidden to hold positions at schools. At the same time, they state that this order was not being implemented at local schools, although they were confident that the SSC would eventually ensure the order full implementation. Teachers persuaded Lviv SSC that they did not doubt its support of their ideas and believed in the Council's ability to persuade the regional Sejm to allocate appropriate funds to increase teachers' salaries (CSHAUL, f. 178, d. 1, c. 1136, pp. 2-2v, 3v).

It should be noted that in addition to material factors, teachers of Bibrka County were also interested in social issues. Apparently, they were seriously concerned about the problem of unqualified teachers, who held positions in schools in the region en masse, mostly under the protection of the local authorities. Of course, the authors of "The Memorial" explained their concern by the decline in respect for teaching by the society, as well as the decline in the 
quality of children's education, which was a consequence of the lack of a proper pedagogical training of such "teachers". "Where are these teacher candidates recruited from? - asked the compilers of the "The Memorial". - These are people, who are very small in the first place, or do not have any studies, people, who cannot find a job anywhere and consider teacher's bread to be a kind of shelter, or, finally, people, who consider the teaching status to be transitional, temporary and hold positions until they do not find another more suitable position. It should be added that women - unmarried old chaperons, who seek refuge in it, also dedicate themselves to this profession" (CSHAUL, f. 178, d. 1, c. 1136, p. 2v). Such a sharp negative characteristics reveals that in fact the authors of "The Memorial" were concerned about rivalry: they, as qualified teachers, who were educated in teachers' seminaries, advocating higher salaries for themselves, constantly emphasized their own education and qualifications. Instead, the presence of a wide range of unqualified teachers, who agreed to work at schools even for a salary of $200 \mathrm{zl}$. per year, underlined the arguments of the teachers - the authors of "The Memorial".

According to school teachers of Bibrka County, only the improvement of living conditions of teachers can prevent the outflow of a professional staff from schools. The improvement will promote the influx of young people to teachers' seminaries, and later to primary schools. At the same time, there was noted the fact of low salaries of teachers in comparison with the salaries of a railway builder, a receptionist or servant in the Sejm building, who were not required to have any education (CSHAUL, f. 178, d. 1, c. 1136, p. 3v).

In the context of the third part of "The Memorial", the teachers proposed to change the system of calculating teachers' salaries, which depended on the location of the place of work. The authors of "The Memorial" proposed to introduce an "advance", which they considered fairer than the current wage system. The essence of the "advance" was that each teacher should start the service of the lowest salary and gradually, "according to merit and years of service", move to higher levels of the salary. The status of teachers in Galicia, according to teachers of Bibrka County, should be divided into 7 classes, each of which should correspond to the annual salary: Class I $-300 \mathrm{zl}$., Class II $-400 \mathrm{zl}$., Class III $-500 \mathrm{zl}$., Class IV $-600 \mathrm{zl}$,, Class V - $700 \mathrm{zl}$., Class VI - $800 \mathrm{zl}$., Class VII - $900 \mathrm{zl}$. Therefore, the authors of "The Memorial" emphasized that the introduction of such "advance" should not be tied to the school location, but to the personality of a teacher. It was emphasized that linking teachers' salaries to the area is harmful, as it encourages teachers to apply for relocation almost every year to other areas, where the wages are higher. The large number of such transfers has a negative impact on education: teachers are often changed at school, they do not work diligently because they hope to be sent to another school. Thus, transfers of teachers depend on the school administration, and it makes teachers ask for favours of officials that negatively affects a moral face of the first ones (CSHAUL, f. 178, d. 1, c. 1136, pp. 4-4v).

In order to ensure the proposed system of wages, the teachers from Bibrka proposed to create a single school regional fund, which would be filled from separate annexes to the taxes, evenly imposed on a large and small property ("because everyone benefits from the charity of the school"), instead, to eliminate all district school funds and any community commitments to maintain schools. From the newly established fund, the administration of which should be entrusted to the SSC, all expenditures should go to schooling in general, and teachers' salaries, in particular (CSHAUL, f. 178, d. 1, c. 1136, pp. 4v-5).

At the same time, the authors of "The Memorial" mentioned about another problem: a teacher, who cares about the post must seek for the favour of various people: a) "lord" (owner 
of a tabular estate), who "does not support the school, because it takes away his workers"; b) a priest, who has a negative attitude towards school, which was taken away from the influence of the Church, he considers school "non-religious" and calls a teacher a "socialist"; c) the whole community of the village or town, the members of which are dissatisfied with the school due to the action of "school coercion" (a compulsory education of all children aged 6-14). As a result, a teacher feels dependent on these forces, on the grace of "dark people". This dependence does not give a teacher any respect, and therefore a teacher is often unable to perform his duties honestly. Therefore, the authors of "The Memorial" asked to release them from such dependence and various influences and to eliminate the procedure of "presents" the appointment of a teacher after the community's approval, the owner of the tabular estate, and etc. The nomination of a teacher, according to Bibrka teachers, should depend only on the teacher's qualification patent and should be carried out by the SSC. This state of affairs would encourage young teachers to pass the qualifying exam as soon as possible and successfully. On the other hand, this would weaken the dependence of teachers even on school inspectors, "who under that review still have great arbitrariness and can arbitrarily control the fate of teachers, often guided by the personal views" (CSHAUL, f. 178, d. 1, c. 1136, pp. 5-5v). It should be noted that this accusation was quite sharp in a general tone of "The Memorial" and it indicated indirectly that the school inspector of Bibrka school district, Jan Tchaikovsky, might not have participated in the conclusion of this document.

Another circumstance, opposed by Bibrka school teachers, was an excessive disciplinary action. They criticized the situation when a teacher was punished by depriving him of the so-called five-year allowance ( $50 \mathrm{zl}$. per year, i.e., $250 \mathrm{zl}$. for all five years). It happened that such a teacher was deprived of the previous five-year allowance and even transferred to a worse position (lower paid) in another area. This teacher had to spend money on moving, which was quite burdensome, especially when he had a family. According to the authors of "The Memorial", there were no similar disciplinary sanctions in other institutions. Therefore, that punishment was proposed to be eliminated (CSHAUL, f. 178, d. 1, c. 1136, pp. 5v-6).

In general, teachers grouped their proposals into the following items:

1. To introduce "advance" and a teacher's status according to years of service.

2. To establish seven classes of teachers' salaries (its size was mentioned above).

3. To link the salary of a real teacher (with a qualification patent) to his personal achievements and merits.

4. To eliminate the district school funds and all the obligations of the communities regarding school needs and to create a single regional school fund, the revenues of which will consist of supplements to the evenly imposed taxes.

5. To eliminate the right of "presents".

6. To appoint teachers only on the basis of obtaining a qualification patent.

7. A teacher, who does not have any qualification patent may not expect to be paid more than 400 zl. per a year.

8. To establish the following disciplinary sanctions: a verbal and written rebuke, a fine, a transfer to another position, a failure at being provided the next "advance", a temporary suspension in promotion, a dismissal from school management, a retirement or, in the worst case, a complete dismissal.

9. The supplement to the fee, to pay for the teacher's apartment, set at $20 \%$ of the fee; the supplement "expensive" (provided only for teachers in areas where living standards were more expensive) $-15 \%$ to the fee; the overpay for school management $-25 \%$. 
10. Reduction of years of service to 30 (CSHAUL, f. 178, d. 1, c. 1136, p. 6).

It should be noted that the weakness of such proposals was the lack of justification in the text of "The Memorial" for items 9 and 10. At the same time, in paragraph 8 there was a direct contradiction with the previous statements, according to which it was proposed to remove fines from the list of disciplinary penalties (and this time they remain).

Such drawbacks, of course, undermined the argumentative power of "The Memorial".

The fourth part of the document was full of, on the one hand, compliments for the SSC and assurances of its ability to solve teachers' problems at the next session of the regional Sejm. At the same time, the teachers, as if justifying themselves, assured the officials from the SSC that while proposing their project, they were guided not only by personal and material views, but also by thoughts about the development of the school and the whole society (CSHAUL, f. 178 , d. 1, c. 1136 , p. 6 v).

It should be noted that "The Memorial" of school teachers from Bibrka County sent to the KSR (and at the same time to the regional Sejm) was never approved by the officials. Excessive budget expenditures were required for the implementation of the salary increase project and salary supplements. And no one wanted to change the system of financing schools and teachers developed over 20 years, to create a separate fund. At the beginning of the 1890-ies, due to the adoption of regular school laws, the size of teachers' salaries even fluctuated somewhat. Thus, according to the Statute of June 15, 1892, the annual salary of public schools teachers was reduced from 400 to $300 \mathrm{zl}$. (Haliv, 2011, p. 53). Almost a third of all teachers in Galicia fell under this reduction in fees. It should be noted that according to an accurate comparison of B. Stuparyk, made on the basis of the article from the newspaper "Public Schooling" ("Szkolnictwo ludowe" - in Polish) (1896, Ч. 3), the annual salary of $400 \mathrm{zl}$. - it was less than spent on the maintenance of the mail horse, and $300 \mathrm{zl}$. - less than the maintenance of a criminal in prison (Stuparyk, 1994, p. 80). In general, only at the beginning of the XXth century there were some positive developments in raising the salaries of teachers in public schools in Galicia.

The Conclusions. Thus, the analyzed "The Memorial" is an extremely interesting historical source, which reveals the level of a social, professional and group activity and solidarity of teachers in the small county of Galicia at the end of the XIXth century. The project elaborated by them, despite the completely uncalculated costs for its implementation, deserves attention, primarily, to the principles that teachers proposed to base the system of "advance": linking the amount of salary (the transition from a lower to higher salary) to the personal success of a teacher, his qualification, experience. At the same time, "The Memorial" testified to the existence of a certain civil position of teachers, who, although timidly, protested against the unsatisfactory social situation, injustices in the provision of a post (the right to "presents", the arbitrariness of officials), holding posts by unskilled and casual people in a pedagogical profession; the authors of "The Memorial" emphasized the negative effects of the protection mechanism (indirectly pointing at corruption in this regard) on the morality of teachers and the quality of education, and etc. It should be noted that the document was signed by both Polish and Ukrainian teachers, who pushed aside their interethnic contradictions in the field of defending the interests of their own professional group. The document is a clear proof of the growth of a legal and social culture of "folk teachers", who gradually became aware of their social importance and dared to take on the role of an active subject in solving the most painful problems of an educational life.

The document is published in the original language (Polish) in compliance with the necessary archaeographic requirements. 
Acknowledgement. We express sincere gratitude to all employees of the Central State Historical Archive of Ukraine in Lviv for their help in finding historical documents.

Funding. The authors received no financial support for the research, authorship, and/or publication of this article.

The document

Wysoka

c. i k. Rado Szkolna Krajowa!

Stan nauczycielski zajmuje w społeczeństwie ważne stanowisko, na jego bowiem barkach spoczywa ciężar oświaty ludowej, jakotéż i wychawania narodu. Z tych tedy powodów zażywa ten stan wszędzie należytei czci, poszanowania obok najlepszego poparcia. Społeczeństwo bawiem kładąc wielką wagę na działalność stanu nauczycielskiego wspiera go na każdym kroku, tak materyalnie, jak i moralnie. Dzięki temu poparciu i ojcowskiej opiece, praca tego stanu błogie wydaje owoce, a przekonać się o tem możemy, gdy spojrzymy na Niemcy, Czechy, i inne kraje, gdzie oświata i postęp i w parze z tymi idący dobrobyt, zakwitły w peraciągu dość krótkiego czasu.

- Niestety! Trudno powiedzieć to o naszym kraju Galicyi!

Wprawdzie istnieją u nas i funkcyonują szkoły ludowe, istnieje stan nauczycielski, ale czy wydaja pożądane owoce? - z ukolewaniem wątpić należy. - Dowadem tego konskrypcya ostatnia, która wykazała zwyż 70\% analfabetów. - I jakaż temu przyczyna?

Podczas, gdy inne kraje monarchii otaczaja pieczołowita opieka szkołę i nauczycielstwo, a widząc w nich połężny srodek do utrzymania idei narodowej, nie szczędząc dla tejże największych ofiar - kraj nasz traktuje nauczycielstwo i szkolnictwo w ogóle po macoszemu. Co najbardziej jest rażącem, to system oszczędnościówy w budżecie szkolnym, ktoŕy gdzie indziej nie ma zastósowania, system, ktoŕy dotkliwie czuć się daje całemu szkolnictwu nietylko materyalnie ale i moralnie - a odbija się na nauczycielach.

Ustawa krajowa postawiła nauczycieli na stanowisku ważnem w społeczeństwie, a tém samém przyznała im wszystkie prawa i przywileje, jakie się ludziom mającym wykształcenie, należą, zapomniała jednak o tém, że odpowiednio do stanowiska, musi być odpowiednie uposażenie materyalne, i uposażyła nauczycieli ludowych wynagrodzeniem, ktoŕe absolutnie nie wystarcza nie tylko na potrzeby, na ktoré nauczyciel już ze swego stanowiska w społeczeństwie jest narażony, ale nawet na otrzymanie jednej osoby, choćby najskromniejsze, a cóż dopiero powiedzieć gdy jest obciążony rodzina.

Sprawa ta nieraz była omowianą nietylko przez nauczycielstwo, ale i przez inne sfery miarodajne, a spodziewać się należy, iz i Wysoka c. i k. Rada Szkolna Krajowa jest przekonaną, iż dotychczasowe stosunki nauczycielstwa pod tym względem są pożałowania godne.

Niema potrzeby dowodzić rzeczy niejednokrotnie już omawianej, dodać jedynie należy, iż między nauczycielstwem obok nędzy zagnieżdziło się ogólne zniechęcenie i rozgoryczenie, zwłaszcza, gdy wszystkie prośby i zabiegi o polepzenie bytu materyalnego są bezskuteczne, a nawet nie ma nadziei, by w najbliższej przyszłości stosunki te zostały korzystnie dla nauczycieli unormowane. -

Nie należy zatem dziwić się, iż z każdym rokiem coraz to więcéj posad nieobsadzonych, gdyż daje się czuć brak sił nauczycielskich, nie dziwić się iż z każdym rokiem powiększa się ilość nauczycieli bez najmniejszej cząsto kwalifikacyi. -

Czy założenie jeszcze jednego seminaryum nauczycielskiego, czy wpływanie na młodzież przez wydziały powiatowe by się poświęcała temu zawodowi, zapobiegnié złemu, 
watpić należy - i sądzić należy iż i Wysoka c. i k. Rada szkolna Krajowa sama najmocniej o tem jest przekonana. -

Młodzież bowiem nie widząc widoków dla siebie w zawodzie nauczycielskim, mając ukończone studya seminaryalne, poświęca się innym zawodom, szuka chleba przy kolei, poczcie, urzędach podatkowych, instytucyach prywatnych, w wojsku lub straży finansowéj w konću. - A iluż to mamy co roku nauczycieli nietylko prowizorycznych ale i rzeczywistych, którzy rezygnują z zawodu i inny sobie obierają?

Co więcej! Brakujące siły nauczycielskie zastepuje się siłami, ktoré nie mają nieraz najmniejszej kwalifikacyi. -

Pomijam już wzgląd na korzysći, jakie odnosi szkolnictwo przez obsadzanie posad nauczycielskich podobnymi indywiduami, lecz podnieść tu należy iż stan nauczycielski w oczach opinii publicznej bardzo a bardzo wiele traci na swej powadze i poszanowaniu dzięki tym stosunkom. -

Bo z kąd że rekrutują się ci kandydaci nauczycielscy? Oto z ludzi ktoŕzy najpierw bardzo małe, lub żadnych studjow nie posiadają, - z ludzi, ktoŕzy nie mogą sobie niegdzie stanowiska znaleść, i chléb nauczycialski uważają za rodzaj przytułka, - albo w konću z ludzi, którzy stan nauczycialski uważaja za stan przejściowy, prowizoryczny, i zajmują posady tak długo, dopóki sobie innego odpowiednieszego stanowiska nie znajdą. - Dodać tu należy iż poświęcają się temu zawodowi nawięcéj kobiety, ktoré skazane na staropanieństwo, szukają w nim przytułku na starość. -

I cóż za korzyść z tego? Oto najpierw szkoła nie funkcyonuje należycie, postąpu nie można się spodziewać, daléj dziejąsię ciagłe zmiany, nieraz i w ciagu roku, bo na czemże zależy takiemu nauczycielowi, jeżli opuszcza szkołę sam kiedy zachce, a wreszcie i powaga stanu nauczycielskiego cierpi na tem, gdyż wielu z tych niby nauczycieli uważając chléb nauczycielski tylko jako środek do tymczasowego nieraz utrzymania, nie są przejęci ważnością powołania, i zachowaniem się swojem na każdym kroku przynoszą tylko wstyd i hańbę stanowi nauczycielskiemu. To téż choć oficyalnie głoszoną bywa cześć i poszanowanie dla stanu nauczycielskiego, w stosunkach jednak codziennych i towarzyskich stoi stan nauczycielski bardzo nieodpowiedno, własnie przez owe pojedyncze jednostki, ktoré wkradłszy się w szeregi nauczycielskie, są tylko zagłada i przeszkoda. -

Nauczycialstwo powitało z wdzięcznością rozporządzenie Wysokiej c. i k. Rady szkol. Kraj., ktoŕe zabrania obsadzania posad osobistosciami niekwalifikowanymi, ze smutkiem jednak patrzeć musi iż powyższe rozporządzenie nie jest ściśle wykonane. -

Nauczycielstwo wyraża nieraz swój żal z tego powodu, glównie dlatego, iż gdyby rozporządzenie to zostało sćiśle wykonanem, wtenczas ogromna liczba nicobsadzonych posad zwrócić by masiała uwaga Wysokiego Sejmu, a nauczycielstwo mogłoby się wtenczas spodziewać polepszenia swego bytu. -

Nauczycialstwo naszego kraju jest przekonane iż Wysoka c. i k. Rada szk. Kraj. jako władza przełozóna jest przychylnia dla tego stanu usposobioną, i właśnie w tym celu wydała powyższę rozporządzenie i nie wątpi iż Wysoka c. i k. Rada szk. Kraj. postara się, by rozporządzenie te zostało w całéj pełni wykonane. - Nauczycielstwo będzie bardzo wdzięczne Wysokiéj c. i k. Radzie szk. Kraj. gdy pozbędzie się z swego grona indywiduów, ktoré nietylko szkole ale i całemu stanowi korzyści nie przynosza. -

Wprawdzie lepsze uposażenie materyalnie nauczycieli mogłoby zapobiedz tym anormalnym stosunkom, gdy tylko większa życzliwość i chęć dla szkolnictwa Wysoki Sejm okazać zachciał. - 
Wtedy nie byłoby powadu narzekać na brak nauczycieli, i ludzi, którzy by z prawdziwem poświęceniem temu zawodowi się poświęcali, wykształconych, inteligentnych, któryby szkole prawdziwą korzyść a nauczycielstwu zaszczyt przynosili. -

Dziś warunki byta są ciężkie, toteż gdyby w zawodzie nauczycielskim stworzyły się choć średniej miary widoki, młodzież poświęcałaby nia się z ochotą. - Jeżli jednak uposażenie terażniesze nauczycieli jest niższe od budnika kolejowego płacy, portyera lub sługusa gmachu sejmowego, od których to ludzi nie ząda się tych studyów, jakich żądają od nauczycieli, a do tego nie ma jeszcze żadnych widoków i awansu w przyszłości, trudno się dziwić, ze szeregi nauczycieli coraz bardziej się przerzadzają. -

Nie watpimy, iż Wysoka ck. Rada szk. Kraj. w ten sam sposób zapatruje się na tę sprawę, jednakże nie o zależności Wysokiej ck. Rady szk. Kraj. od Wysokiego Sejmu, wie i o tem zé mało tu zdziałać może jeżli Wysoki Sejm śwéj dobrej woli ku temu sam nie zaznaczy. Jednakże nauczycielstwo jest przekonane iż głos Wysokiej ck. Rady szk. Kraj. jako władzy fachowej ma wiele znaczenia, a poparcie próśb naszych z jej strony możé wiele przyczynić się do pokierowania sprawy na dobre tory. - To téż nauczycielstwo nie wątpi, iż Wysoka ck. Rada szk. Kraj. popiera na każdym kroku ich słuszne życzenia, a choć one nie znajdują posłuchu, tam gdzie należy, żwyne to przekonanie iż może licżyć w każdej chwili na życzliwe poparcie naszej Wysokiej władzy. -

Wprawdzi omawiano już nie raz sprawą polepszenia bytu stanu nauczycielskiego, wyłoniały się różne projekta, lecz żaden z nich nie zadowolnił żądań nauczycieli, nie uczynił zadość życzeniom w kierunku awansu. - Nie tyle ubija się nauczycielstwo o podwyższenie płac, ile o awans. Zaprowadzenie awansu powitałoby nauczycielstwo z radością, gdyż byłby on aktem sprawiedliwości dla nauczycieli. - Wtenczas każdy nauczyciel poczynałby służbę od najniższej płacy, a w miarę zasług i lat służby przechodziłby do coraz wyżczej płacy. Byłyby wtenczas pewne widoki, i nauczycielstwo byłoby pewnem, iż nie protekcya, lub inne względy, jakto dotychczas się praktykuje wpływałyby na awans, lech jedynie zasługa. - Dziś z przykrością patrzeć trzeba na to, jak system protekcyjny kwitnie w całéj pełni. Ukończony seminarzysta mając protekcyę, dostaje lepszą posadą, jak nauczyciel ktoŕy już dłuższy czas pracuje, a czyż nie może już być większej niesprawiedliwości, jeżli osoba niemająca często najmniejszej kwalifikacyi otrzymuje posadę jakiej nie ma nauczyciel z kwalifikacyą i zasługą?

To też nauczycielstwo nie może patrzeć na istniejący stan rzeczy obojętnem okiem, i celem zniknięcia go pragnie zaprowadzenia awansu. - W tym celu ma być ułożony krajowy status nauczycieli według lat służby, status ten ma być podzielonym na siedem klas, a do każdéj klasy ma być przywiązana płaca, a mianowicie:

$\begin{array}{ll}\text { I klasa } 300 \mathrm{zl} . & \text { IV klasa } 600 \mathrm{zl} . \\ \text { II }, 400, & \text { V }, 700, \\ \text { III }, 500, & \text { VI }, 800,\end{array}$

VII klasa $900 \mathrm{zl}$.

W dalszem następstwié zaprowadzenia awansu musi być charakter rzeczywistego nauczyciela i płaca nie do miejscowości, lecz do osoby nauczyciela. Przywiązanie płacy i charakteru rzeczywistego nauczyciela do miejsca dzieła bardzo szkodliwie na rozwój szkoły, jakoteż i na stosunki służbowe nauczycieli. - Każdy bowiem nauczyciel stara się co roku o lepsza posadę i z tego powodu ciągle się przenosi, a na tem cierpi najpierw szkoła, ktoŕa przez coroczne zmiany nauczycieli nié wiele korzysta. Krażdy bowiem nauczyciel, który się spodziewa iż dłuzej nad rok lub dwa na jednéj posadzie nie będżie, pracować przeciż 
dla swego następcy nie będzie tak, jakby to pracował, gdyby wiedział zé dłuzéj tu zostanie. Zresztą częsta zmiana nauczycieli już ze względów pedagogicznych nie jest wskazaną. Cierpi daléj na tem i nauczyciel, który albo zmuszony, lub na własną prośbę przenosi się, i naraża się na straty materyalne, a wreszcie przywiązanie płacy i charakteru rzeczywistego nauczyciela do miejsca wplywa niemoralnie na samych nauczycieli, którzy ubiegając się o jedną i ta samą posadę szukają różnych dróg i sćieżek celem otrzymania takowej wskutek czego powstają miedzy niemi niejednokrotnie niesnaski i nieporozumienia. - Cierpią w konću na tem nauczyciele rzeczywiści, ktoŕzy nie moga się przenieść prowizorycznie na lepszą posadą, gdy ta się otworzy, i z żalem patrzeć musza, jak takowa zajmuje nauczyciel mniej zasłużony. -

Z tych łady względów pragnęłoby nauczycielstwo by płaca i charakter służbowy nauczyciela był przywiązanym nie do miejsca lecz do osoby, tak by nauczyciel na miejścu, bez przenoszenią się mogł awansować. -

Aby jednak rzecz tę przeprowadzić, należałoby stworzyć jeden fundusz szkolny krajowy przez osobne dodatki do podatków, ktoré mają być równomiernie rozłożone tak na większe jak i na mniejsze własności, gdyż wszyscy zarówno z dobrodziejstwa szkoły korzystają - a natomiest znieść wszelkie fundusze szkolne okręgowe i wszelkie zobowiązania gmin na cale utrzymania szkół - i z tego funduszu, administrowanego przez Wysoka ck. Radą szkol. Kraj. opędzać należałoby wszystkie wydatki na potrzeby szkolnictwa w ogólności, a na opłacanie wszystkich bez wyjątku nauczycieli w szczególności. -

Przywiązanie płacy i charakteru rzeczywistego nauczyciela do miejsca naraża go jeszcze i na inne nie żbyt przyjemne okoliczności. Sytuacya nauczyciela starającogo się o stałą posadę i o podpisanie prezenty jest nie do pozazdroszczenia. - Dbać musi on bowiem o łaską różnych ludzi w gminie i tak: dziedzica, ktoŕy nie popierza szkoły, dlatego że zabiera mu robotników, księdza, ktoŕy przeciwny szkole zé usunięto ję z pod wpływu kościoła, a który uważa ją za bezwyznaniowa a nauczyciela nazywa socyalistą, całéj gminy wreszcie, ktoŕa jest z nia niezadowoloną, iż zastósowuje z całą energią przepisy co do przymusu szkolnego. W tym wypadku jest zatem nauczyciel miądzy kowadłem, gdyż nie chciałby się ani róznym osobistościom ani przełożonéj władzy narazić. - Czujé się zatem zależnym od wszystkich a nieraz zdany jest na łaskę ciemnych ludzi. Czy ta zależność nauczycieli przyczynia się do utrzymania jego powagi i poszanowania, czy może wobec tego nauczyciel wypołniać swe obowiązki sumiennie i bezwzględnie nie krępując się niiczem? Wątpię! -

Nauczycielstwo zatem pragnie być uwolnione od tej nienatyralnéj zależnosci i różnorakich wpływów, nié chce być krępowanem w pełnieniu swych obowiązków, i chce miać tylko jedną władzą, przed którą odpowiada za siebie. -

Nauczycielstwo pragnie zatem by podpisywanie prezenty zostało zniesionem, a nominacya rzeczywistego nauczyciela by mogła być wydana na mocy uzyskanego patenta kwalifikacyjnego, wprost z Wysokiej ck. Rady szk. Kr. i bez przywiązania do miejsca. Zyskałoby na tem nauczycielstwo po piezwcze: niezależność wobech wielu czynników, po drugie, gdyby awans dalszy np. do III klasy zastrzeżona jedynie dla tych, którzy wykazuą się patentem kwalifikacyjnym, staraliby się sami nauczyciele o jak najrychlejsze zdawanie tego egzamina we własnym interesie, i przełożone władze nie widziałyby konieczności zmuszać ich do tego, jak się to niestety dziś praktykujé. - Po trzecie, zyskałoby nauczycielstwo to, iż nie byłoby narazone na szykany inspektorów szkolnych, ktớzy pod tym względem mają dotychczas wielką samowolność i mogą dowolnie rozporządzać losem nauczycieli, kierując się nieraz względami osobistymi. 
Lacznie z spawa polepszenia bytu materyalnego jest sprawa zmiany kar dyscyplinarnych. Kary dyscyplinarne jakie dotychczas istnieją są za zbyt surowe i zostawiają zbyt otwarte pole do samowolnego zastósowania. Nauczyciel dostający naganę, traci na pięć lat pięciolecie tj $250 \mathrm{zł} \mathrm{w}$ ileż razy trafia się ze traci i poprzednie pięciolecia ktoré posiada, a w dodatku zostaje jeszcze przeniesionym na gorszą posada. - Wtenczas traci na tysiące, i zostaje zupełnie zrujnowanym, zwłaczcza gdy ma jeszcze rodzinę. - Jeżli powrowńamy kary, jakie mają zostósowanie w innych instytucyach, ktoŕe nieraz materyalnie więcéj tracą przez niedbalstwo swych funkcyonaryuszów, jak np. nagana, kara pienięzńa, pominięcie w awansie, przeniesienie, spensyonowanie lub oddalenie w najgorszym wypadku, a porównamy skutki dyscyplinarki u nauczycieli, ktoŕzy nie narażaja, nikogo w razie zaniedbania swych obowiązków na stratę materyalną, to nie dziwić się, iż nauczycielstwo czuje się pod tym względem bardzo pokrzywdzonem w swych prawach. - Nauczycielstwo sadzi, iż zaniedbanie obowiazków powinno być karanem nie tak jednak że by płaca zasłużana mogła być odobrana. Ta powinna być nienaruszona pod żadnym warankiem. -

Jeżli tedy streścimy żądania nauczycieli, w kierunku polepszenia bytu materyalnego, przedstawiaja się one sposób następujący:

1. zaprowadzenie awansu i statusu według lat służby.

2. ustanowienie siedm klas płać; a mianowicie:

I kl. -300 zł. II kl. -400 zł. III kl. -500 zł.

IV , $-600 \mathrm{zl}$. V , $700 \mathrm{zl}$. VI , $800 \mathrm{zl}$.

VII , $-900 \mathrm{zł}$.

3. Płaca i charakter rzeczywistego nauczyciela jest przywiązany do osoby.

4. zniesienie funduszów okręgowych, i wszelkich zobowiązań gmin na cele szkolne a utworzenie jednego fundusza szkol. kraj. z dodatków do podatków równamiernie rozłożonych. -

5. Zniesienie prawa prezenty.

6. Nominacyą rzeczywistego nauczyciela następuje na podstawie uzyckanego patenta kwalifikacyjnego.

7. Nauczycial nie mający patenta kwalifikacyjnego nie może awansować wyżej nad 400 zł. -

8. Kary dyscyplinarne są:

nagana ustna, pisemna, pieniężna /:stopniowo:/, przeniesienie, pominięcie w awansie, czasowe zawieszenie w służbie, odebranie kierownictwa, spensyanowanie lub w najgorszym wypadku całkowite wydalenie. -

9. Dodatek na mieszkanie o ile go nie ma w naturze w wysokości $20 \%$ pobieranij płacy; drożyzniany w wysokości $15 \%$ za kierownictwo $25 \%$. -

10. Zniżenie lat służby do lat 30.-

Te żądania przedkłada nauczycielstwo Wysokiej c. i k. Radzie szkolnej Kraj. w nadziei iż Wysoka c. i k. Rada szk. Kr. weżmie je pod swa rozwaga i poprze takowe na najbliższej sesyi Wysokiego Sejmu. - Nauczycielstwo przedkładając niniejszy projekt kieruja się wzgledami nietylko czysto osobistymi i materyalnymi, ale również względami o dobro i rozwój szkoły naszej oraz społeczeństwa, na ktorego pracują. Nie watpi, iż poparte przez Wysoka c. i k. Rada szk. Krajowa znajda posłuch w sferach kompetentnych, tem bardziej iż zasługują na to, by praca ich ciężka i mozolna, była wynagrodzona tak, jak sprawiedliwość nakazuje. Wprawdzie szkoła nasza nie wydała jeszcze tych owoców, jakichby spodziewać się należało, lecz właśnie przyczyny szukać należy w zbyt lichem materyalnem zaopatrzeniu nauczycieli. Nauczycielstwo dla tego nie watpi, iż jeżli powyższe żądania pomyślnym skutkiem uwieńczone zostaną, rozwój 
szkolnictwa w kraju naszym wejdzie na inne, bo lepsze tory, i tuszyć można, że dojdziemy prędzéj do tego ideału, jakiśmy sobie wytknęli, by podnieść biedny i skołatany stuletnimi wypadkami kraj nasz do rzędu innech krajów cywilizowanych. -

Nie watpimy iż Wysoka c. i k. Rada szkol. Kraj. jako nasza przełożona Władza jest życzliwie usposobiona dla naszéj sprawy i dlatego przedkładamy jéj w pierwszym rzędzie nasze żądania, ktoŕe zarazem przedkładamy równocześnie Wysokiemu Wydziałowi Krajowemu i Wysokiemu Sejmowi, - i żywimy nadzieję, iż doznamy ze strony nasżej Wysokiej Władzy wszelkiego zyczliwego i słusznego poparcia. -

Bobrka dnia 10 pażdziernika 1891.

(the signatures of 76 teachers)

The historical source: Central State Historical Archives of Ukraine in Lviv, f. 178, d. 1, c. 1136, pp. 1-8.

\section{BIBLIOGRAPHY}

Baik, L. \& Mitiurov, B. (1965). Stan narodnoi osvity i pedahohichnoi dumky na zakhidnoukrainskykh zemliakh $v$ period panuvannia Avstro-uhorskoi monarkhii [The state of public education and pedagogical thought in Western Ukraine during the reign of the Austro-Hungarian monarchy]. Drohobych, 60 p. [in Ukrainian]

Baranowski, B. (1910). Szkolnictwo ludowe w Galicyi w swym rozwoju liczebnym od r. 1868 do r. 1909 [The public education in Galicia in its numerical development from 1868 to 1909]. Lwów, 47 p. [in Polish]

Baranowski, M. (1896). Pogląd historyczny na zmiany w ustroju szkół ludowych w Galicji po roku 1772 [Historical view on changes in the system of folk schools in Galicia after 1772]. Rodzina $i$ Szkoła, 18, 420-428. [in Polish]

Blahyi, V. (1999). Shkilnytstvo v Halychyni na poch. XX st.: istoryko-sotsiolohichnyi aspekt [Schooling in Galicia at the beginning of the XXth century: historical and sociological aspect]. Lviv, 75 p. [in Ukrainian]

Fiutowski, T. (1913). Szkolnictwo ludowe w Galicyi w dobie porozbiorowej [The public education in Galicia during the post-partition era]. Lwów, 80 p. [in Polish]

Franko, I. (1986a). Nashi narodni shkoly i yikh potreby [Our public schools and their needs]. Franko I. Zibrannia tvoriv. U 50 t. (T. 46, Kn. 2, pp. 108-115). Kyiv. [in Ukrainian]

Franko, I. (1986b). Shcho koshtuiut nashi narodni shkoly? [What are our public schools worth?]. Franko I. Zibrannia tvoriv. U 50 t. (T. 44, Kn. 1, rr. 145-150). Kyiv. [in Ukrainian]

Fylypchak, I. (2009). Z istorii shkilnytstva na zakhidnii Boikivshchyni (vid 1772 - 1930) [From the history of schooling in Western Boykivshchyna (from 1772 - 1930)]. Litopys Boikivshchyny. Vyp. 1 (Chysla 1, 2 za 1931 - 1933 rr.). Lviv : Kameniar, 65-132. [in Ukrainian]

Haliv, M. (2011). Materialne zabezpechennia silskoho vchytelstva Halychyny u 1867 - 1918 rr. (na prykladi Drohobytskoho povitu) [The financial providing of rural teachers of Galicia during 1867 - 1918 (based on Drohobych district)]. Problemy humanitarnykh nauk. Vypusk 28. Istoriia, 47-63. [in Ukrainian]

Kravchenko, U. (1975). Spohady uchytelky [Memoirs of a teacher]. Uliana Kravchenko. Tvory. Povne vydannia (u 100-richchia zhinochoho rukhu) (pp. 553-639). Toronto. [in Ukrainian]

Lozynskyi, M. (1906). Ukrainska shkola v Halychyni [Ukrainian school in Galicia]. Nova hromada, 10, 96-112; 11, 51-71. [in Ukrainian]

Mayer, Z. (1899). Z krainy nędzy. Stanowisko nauczyciela ludowego w stosunku do naszego spoleczeństwa [From the land of poverty. The public teacher's position in relation to our society]. Nowy Sącz, 86 p. [in Polish]

Petriv, R. (2002). Realizatsiia natsionalnoi idei ukraintsiv Skhidnoi Galicia v rozvytkovi ukrainskoho shkilnytstva (1772 - 1916) [Realization of the national idea of the Ukrainians of Eastern 
Galicia in the development of Ukrainian schooling (1772-1916)]. Boikivshchyna. T. 1. Drohobych, 152-159. [in Ukrainian]

Rzemieniuk, F. (1891). Unickie szkoły poczatkowe w Królestwie Polskim i w Galicji 1772 - 1914 [Uniate elementary schools in the Kingdom of Poland and in Galicia 1772 - 1914]. Lublin: Tow-wo Nauk. KUL, 348 p. [in Polish]

Schmitt, H. (1874). Szkoły ludowe w Galicyi w roku 1873/74 [The people's schools in Galicia in 1873/74]. Szkoła, 46, 427-429; 47, 439-442; 48, 453-454; 49, 457-459; 50, 469-470; 51, 477-481; 52, 489-492. [in Polish]

Sholohon, L. (2004). Stan ukrainskoi pochatkovoi ta serednoi osvity v Halychyni (druha polovyna XIX - pochatok XX st.) [The Ukrainian primary and secondary education in Galicia (the second half of the XIXth - the beginning of the XXth century)]. Galicia. Naukovyi i kulturno-prosvitnii kraieznavchyi chasopys, 10, 87-92. [in Ukrainian]

Stuparyk, B. (1994). Shkilnytstvo Halychyny (1772 - 1939) [Schooling in Galicia (1772 - 1939)]. Ivano-Frankivsk, 144 p. [in Ukrainian]

Stynska, V. V. (2004). Systema shkilnytstva v Halychyni (kinets XIX - pochatok XX st.) [The system of schooling in Galicia (the end of the XIXth - the beginning of the XXth century)]. (Extended abstract of Candidate's thesis). Ivano-Frankivsk, 20 p. [in Ukrainian]

Szematyzm. (1891). Szematyzm Królestwa Galicyi i Lodomeryi z wielkiem księstwem krakowskiem na rok 1891 [Shematism of the Kingdom of Galicia and Lodomerya with the Grand Duchy of Kraków of 1891]. Lwów: Nakł. Galic. c.k. Namiestnictwa, 976 + XVIII p. [in Polish]

Tsentralnyi derzhavnyi istorychnyi arkhiv Ukrainy, m. Lviv [Central State Historical Archive of Ukraine, Lviv-CSHAUL]

Varianytsa, A. O. (2018). Uchyteli narodnykh shkil Halychyny druhoi polovyny 19 - pochatku 20 stolittia [Elementary School Teachers in Galicia in the second half of the 19th and the beginning of the 20th centuries]. (Candidate's thesis). Lviv, 316 p. [in Ukrainian]

Vorobkevych, T. \& Vorobkevych, A. (2007). Pryvatni shchodennyky pro zhyttia ukrainskoho vchytelstva Galicia kintsia XIX - pershoi polovyny XX st. [Private diaries about the life of Ukrainian teachers in Galicia at the end of the XIXth - the first half of the XXth century]. Buttia v mystetstvi: zbirnyk naukovykh prats $i$ materialiv na poshanu Stepana Kostiuka z nahody 80-richchia (pp. 141-150). Lviv. [in Ukrainian]

The article was received on November 27, 2019. Article recommended for publishing 26/08/2020. 